Саша Марковић

Универзитет у Новом Саду

Педагошки факултет у Сомбору

milnik.markovic@gmail.com
Оригиналан научни рад

примљено: 9. јун 2014

прихваћено: 1. октобар 2014

\title{
ПОЛИТИЧКА ИСКУШЕЊА ИДЕНТИТЕТА СЛОВАКА У ВОЈВОДИНИ 1919-1941.
}

Сажетак: Словачка заједница у Војводини, односно долноземски Словаци, преко својих политичких представника не само да је поздравила формирање југословенске државе већ је били и активни учесник у овом процесу. Делећи са Србима али и са осталим немађарским народима искуство обесправљености, Словаци су се у очувању свог идентитета у Аустроугарској монархији ослањали и на словенску сарадњу. Она је остваривана кроз културно-уметничке везе које су продубљивале снажан осећај словенске узајамности. Југословенски концепт, сматрали су, представљао је тренутак остварења тог осећаја. Ипак Идеализам државу подстиче, али је не ствара. Обједињени геополитички простор Краљевине Срба, Хрвата и Словенаца био је врло комплексан. Политичке странке су, већином, прихватиле нову државу али су истрајале на традиционалном концепту и програму својих организација. Последица тога био је сусрет еуфоричног и остваривог осећаја једних са опрезним и подозривим осећајима других. У наступајућем политикантству многе наде су се распршиле а југословенска држава је, на самом свом почетку, преиспитивала свој концепт идентитета. Центри политичке моћи били су ван парламента иако је требало да он буде његово средиште. Државу је оптеретило национално и уставно питање. У таквој атмосфери Словаци су сматрали да је њихово политичко организовање веома битно, као и сарадња са грађанским странкама. Уважавајући сарадњу Чехословачке са Краљевином, они су прихватили монархистички облик владавине иако су имали и склоности ка републиканизму. Подложна утицају Радикалне и Демократске странке, Словачка народна странка је покушавала да сарађује и са једном и са другом. Током доношења одлука о сарадњи била су присутна предизборна обећања али и притисак у вези са савезништвом. Политички лидери Словака: браћа Мичатек - Владимир и Људевит, затим Јанко Буљик и др. имали су велику одговорност у вези са доношењем одлука. Увођење диктатуре 1929. године услед неодрживих искључивих приступа довело је до престанка страначког живота. И Словачка народна странка је престала са радом и више се није реорганизовала. Одређени њени представници, попут Јанка Буљика, прихватали су иницијативе у оквиру опозиције а ради политичке препознатљивости Војводине, али Словаци су као заједница били посвећени очувању свог културно-просветног израза и одрживог економског положаја.

Кључне речи: Словаци, странка, програм, држава, идеје. 


\section{Историографски домети}

Проучавање политичког израза Словака Војводине у прошлости у српској историографији није било занемарено, али је и пажња била скромна. Таква ситуација је била и очекивана уколико су теме истраживања биле општијег карактера и тиме условљавале ограничен обим бављења политичком историјом тзв. долноземских Словака - углавном Словака из Војводине. ${ }^{1}$ Продорније истраживање овог проблема видљиво је у оквиру бављења политичком историјом Војводине. У оквиру истраживања међуратног периода истичу се радови у којима је реч о страначком животу и сарадњи Словачке народне странке са Радикалном ${ }^{2}$ и Демократском странком ${ }^{3}$ као и о ширем грађанском опозиционом изразу након диктатуре. ${ }^{4}$ Недостатак ових радова односи се на парцијално коришћење историјских извора и изостављање појединих релевантних. Ово не умањује значај написаних радова, напротив, њихов тематски оквир увелико је одређивао модалитет приступа и, у складу с тим, примерено је био посвећен истраживању извора који се односе и на политичку прошлост Словака. Поједини истраживачи из Војводине, словачке националности, били су посвећени раду о расветљавању прошлости свог народа и у овом периоду. Њихова достигнућа представљају драгоцен допринос и незаобилазну литературу за проучавања у будућности. ${ }^{5}$ Словачка република подстиче историографска истраживања и кроз школовање и научно напредовање својих сународника у матичној држави. ${ }^{6}$ Истраживања се врше и у региону. ${ }^{7}$ Све то утиче на продубљивање сазнајног домета али и резултати подстичу на покретање нових истраживања. И поред видног напретка стиче се утисак да постоји известан паралеризам који је вероватно настао услед недовољне комуникације српских и словачких истраживача. У последње време, а руководећи се традицијом тема које обједињују и једне и друге у бројним преломним историјским догађајима, долази до

\footnotetext{
* Текст је настао као фазни резултат рада на пројекту Друштвени односи Срба и Хрвата, национални идентитет и мањинска права са аспекта европских интеграција (број 47024) Министарства просвете, науке и технолошког развоја Републике Србије.

1 Зоран Јањетовић, Деца ияарева, пасторчад краљева, националне мањине у Југославији 1918-1941, Београд 2005.

${ }^{2}$ Слободан Бјелица, Радикали у Војводини, 1919-1929, Београд 2005; Слободан Бјелица, Војвођански радикали и Словаци, Зборник радова „Српско-словачке везе“, Трнава 2013, 90-97.

${ }^{3}$ Бранислав Глигоријевић, Политичка иступања и организачија Словака и Чеха у Краљевини СХС, Зборник Матице српске за историју, бр. 24, Нови Сад 1981, 137-155.

${ }^{4}$ Саша Марковић, Национално и уставно питање у делатности странака у Војводини 1929-1941, докторска дисертација, Нови Сад 2008; Саша Марковић, У потрази за политичким идејама Јанка Буљика, Зборник радова „Српско-словачке везе“, Трнава 2013, 98-116.

${ }^{5}$ Jan Kmeć, Slovačko-srpska saradnja u matičnom duhu krajem prošlog i početkom ovog veka, Novi Sad 1992; Jan Kmeć, Vlastita logika slobode slovačke nacionalne manjine u Vojvodini. Politicki položaj manjina u Saveznoj republici Jugoslaviji. Zbornik SANU, Beograd 1996; Kovačica pamatá: zbornik z vedeckeho sympozia Kovačica pamat, Matica Slovenská, Slovakia, 2007; Јан Сирацки, Велика народна скупптина и војвођански Словаџи, Зборник „Присаједињење Војводине Краљевини Србији 1918“, Нови Сад 1993.

${ }^{6}$ Gabriela Gubobvá, Slovenská menšina v kontexte poltických udalostí v Královstve SCHS 1918-1929, докторска дисертација, Братислава 2009.

${ }^{7}$ Влатка Дугачки, „, Мањинска посла“ - политичко организирање чешке и словачке мањине на изборима за Уставотворну скупштину, Загреб 2012, 389 - 413. file:///C:/Users/sasa/Downloads/7_Dugacki_CSP_2012 2.pdf.
} 
све учесталијих сусрета који нас упознају са достигнутим и упућују на још интензивнију сарадњу. Зборници радова који се појаве на основу такве сарадње драгоцен су допринос не само науци већ и јачању наратива већ постојећих културних веза. ${ }^{8}$

У време присаједињења 1918.

Велики рат, односно Први светски рат, почетком јесени 1918. године, услед изнурености и исцрпљености његових актера привођен је крају. Антанта, видно ојачана уласком Сједињених Америчких Држава у рат и поред револуције у Русији, постајала је све снажнија и њена премоћ имала је трајни карактер. Ипак ситуација на фронтовима захтевала је огромна прегнућа и спремност на бројне жртве. (Не)надани успех пробоја Солунског фронта и дубоки територијални продор који су предводили углавном припадници војске Краљевине Србије довели су до пометње међу чланицама Централних сила. Упркос намерама конзервативне елите Аустроугарске монархије да придобије становнике без обзира на националну припадност, за редефиницију државног устројства њена постратовска афирмација доведена је у питање. На рушевинама некадашњих царстава, савезници су прихватањем постулата о праву народа на самоопредељење чији је иницијатор био амерички председник Вилсон Вудро стимулисали формирање држава дотада национално и демократски обесправљених народа. Тој групи народа, којима се указала јединствена прилика, припадали су и Срби и Словаци из дунавске монархије. За Србе национална идеја била је јасна и одређена. Њен пијемонт била је Краљевина Србија и њен политички програм југословенског уједињења донет још тзв. Нишком декларацијом почетком децембра 1914. године. У месецима превирања октобар-новембар 1918. долноземски Словаци, односно Словаци из Војводине, ослањајући се на искуства културно-политичке сарадње са Србима у Аустроугарској монарији и правилно процењујући утицај присуства и одлучности Краљевине Србије сматрали су да је њихов прави пут подршка стварању нове југословенске државе. Ипак, требало је много више од самог усхићења да се конкретни државни и политички интереси остваре. Новоформирана мађарска влада на челу са Михаљом Карољијем није мирно гледала распад своје територије. Позивајући се на споразум који је потписала са Антантом, ${ }^{9}$ мађарска влада бројним посетама и обиласцима терена желела је да представи нов демократски кредибилитет Мађарске и придобије и немађаре за визију своје републике. Ипак готово ${ }^{10}$ општи предратни и ратни консензус мађарске политичке елите око националистичке искључивости утицали су на атмосферу општег неповерења у прокламовану демократизацију мађарске

\footnotetext{
${ }^{8}$ Српско-словачке везе, из историје, садашњости и будућности, Zborník z konferencie srpsko-slovkenské vzT̄ahy, z histórie, súčasnosti, a budúcnosti, Трнава 2013.

9 Војна конвенција о примирју потписана је између делегата команде савезничких војних снага и представника нове владе Мађарске, 13. новембра 1918. године. Њом је било предвиђено да административна управа остане затеченим органима власти, дакле мађарским, а Антанти је била предвиђена војна управа.

${ }_{10}$ Детаљније вид.: Оскар Јаси, Будућност Монархије: пропаст Двојне монархије и сједињене подунавске земље, Сремски Карловци 1996.
} 
државе. С обзиром на то да је непријатељ дунавске монархије била и Краљевина Србија, положај српског народа у њој био је изузетно тежак. Многи виђенији Срби су били под снажним притиском репресивног државног апарата и интернирани или затворени у бројним казаматима. У таквој ситуацији, што није остало непримећено, ${ }^{11}$ неки су показали малодушност а тумачили је лојалношћу. И словачка заједница се суочила са снажним притиском манифестације родољубља и војног учешћа. У неким случајевима тумачења ратне аустроугарске елите о потпуној лојалности Словака имала су своје упориште. Томе у прилог ишла је и ригидна примена ратних закона са драконским мерама казне. „Характерной для всех является всеобщая безусловная лояльность и глубоко укоренная ненависть к сербам, преумноженная изза судьбы любимого погибшего престолонаследника.“12 Овакав став, није искључено, могао је да произлази и из привржености једног дела представника Словака али и Чеха идеји о модернизацији Аустроугарске монархије кроз стварање словенске федералне јединице, ${ }^{13}$ а која се идејно испољавала и као аустрославизам. „Именно Карел Крамарж в то же самое время опять поднял на щит давно отвергнутую идею австрославизам и попытался вновь сформулировать ее в условиях дуалистичкеской империи.“14 Ипак, притисак амалгама јединственог мађарског политичког народа условио је да наизлед лојалан приступ држави, пре свега, буде притворни чин немађарских народа који се нису слагали са концептом државе која почива на националној и најширој културној дискриминацији. Ослањајући се на идеје словенске интегративне узајамности из времена настанка Матице српске и Матице словачке, као и на страначку позиционираност, политички представници ова два народа покренули су иницијативу међусобне сарадње ради поспешивања свог положаја у држави. Последица тога био је добро организован Конгрес народа у Будимпешти 1895. године на којем је политичка елита немађара одлучила да ради на свом удруживању у борби против државног нихилизма. Од тог времена па до 1914. сарадња је имала и своје успоне и падове, скретања и повратак, али није обустављала континуитет иако је притисак власти био све неодмеренији. ${ }^{15}$ Конформизам и опортунизам помешани са оскудним демократским искуством

\footnotetext{
11 „Први дани рата су били, вероватно, одвратна позорница кукавичлука и подлости код Срба у Угарској...“ Васа Стајић, Учешће српског друштва у мојој судбини, Рукописно одељење Матице српске (даље: РОМС), М 8.756. „Ми смо кукавице којима је српство само на језику, а када би требало делом, па и главом и крвљу посведочити то - онда се одричемо и имена свог.“; О првим данима рата, по сећањима др Јована Јоче Лалошевића, Историјски архив Сомбор, Ф-56, инв. број 549.

${ }^{12}$ Magyar Orszagos Leveltar, Budapest, Miniszterelnokseg K-26. 1915-XII-1034. cs. 5807. alapszam. K. u. k. Armeeoberkommando an I. Tisza, 18. 10. 1915. Цитирано према: Р. Голцев, 1918г.: Словаки между лояльностью Габсбургам, Венгерскому королевству и новой республике, выпуск 6, том 1, Москва 2012, 153.

13 „Једном је он престолонаследнику [мисли се на Милана Хоџу, једног од најзначајнијих представника Словака у дунавској монархији - примедба С. М.]... чак и рекао: 'Или ће Монархија остварити наше идеале у оквирима своје (федеративне) државности, или ћемо се отцепити и остварити сами свој национални сан путем уједињења са нашом браћом.“; Kristoffy, Kálvária, Bp, 1927, 743; цитирано према: А. Лебл, Грађанске партије у Војводини 1887-1918, Нови Сад 1979, 231.

${ }_{14}$ В. Доубек, Карел Крамарж и Томаш Гарриг Масарик: ческаја концепиија развала Австро-Венгрии, выпуск 6, том 1, Москва 2012, 111. Вид. у истом зборнику и М. Главачка, Причины распада Габсбургской монархии: Взгляд из Праги, 101-109.

${ }^{15}$ Детаљније вид. и С. Марковић, У потрази за политичким идејама Јанка Буљика, 98-116.
} 
представљали су озбиљан проблем страначке артикулације политичких интереса и Срба ${ }^{16}$ али и Словака. ${ }^{17}$

Како је пораз Централних сила био све извеснији, и на овим просторима је отпочело територијално и национално уобличавање будућих држава. У том судару тек афирмисаних националних идеја кроз нове државне пројекте са изазовима демографске структуре становиништва, уколико би се чиниле грешке редукционизма Аустроугарске монархије, постојала је могућност да искуључивост буде одабран континуитет а реваншизам основна политичка тековина. ${ }^{18}$ Намера да се такве грешке избегну постојала је и код Словака и код Срба, штавише, националистичка идеологија био је основни аргумент у образложењу неодрживости концепта нове мађарске републике. Почетком октобра 1918. стварају се народни одбори Срба, Буњеваца и Словака, а њихова намера била је да активно учествују у стварању нове југословенске државе. ${ }^{19}$ Најзначајнији народни одбор Срба, који је и предводио овај процес присаједињења, био је формиран у Новом Саду. Словаци су своје месне одборе формирали у контексту обнављања рада Словачке народне странке. „Vytvorená bola organizačná štruktura Národnej Rady dolnozemských Slovakov. Predsedom bol dr. L'udovit Mičátek. Pozostavala z ústredneho výboru, krajových oddelení a miestnych výborov. Miestne výbory boli vytvorene v obciach a starali sa o bezpečnost' života a majetku, tiež o verejnu správu, lebo mnohí mad'arskí úradnici boli odvolaní, alebo opustili svoje pracovne miesta pod nátlakom verejnosti. V krajovom výbore boli 2-4 predstavitelia $\mathrm{V}$ závislosti od počtu obyvatel'stva a $\mathrm{v}$ ústrednom výbore boli 4 predstavitelia každeho kraja.“20 На страначком састанку одржаном 10. новембра 1918. у Новом Саду, представници словачке заједнице су истакли своју приврженост праву на самоопредељење и стварању југословенске државе као остварењу идеала словенске узајамности. „Báčanski Slováci i v mene sriemských slovenských obci srdečne pozdravujeme novosadskú Srbskú Národnu Radu a osvedčujeme sa, že sa s radost'ou pripojujeme na základe wilsonovskeho prava samourčovania národov $\mathrm{k}$ bratom Srbom a chceme jim byt' napomoci vo všetkych ich spravodlivých snahách. V tomto bratskom objati úfame najst' posilu lepšej a štastnejšej budúcnosti svojho slovenského národa.'‘21

Начин на који ће се тај акламативни процес остварити био је предмет полемике. Постојала су два приступа. Група политичара демократски оријентисаних, иако нису успели да створе странку, 22 предвођена Тихомиром Остојићем сматрала је да уједињење у нову југословенску државу треба да се оствари преко сарадње Народног вијећа Словенаца, Хрвата и Срба из Загреба са

\footnotetext{
16 Детаљније вид. и: С. Марковић, Политиканство или пролегомена Демократске странке код војвођанских Срба Аустроугарске монархије, Истраживања, бр. 23, Нови Сад 2012, 415-432.

${ }^{17}$ Ближе вид. и: С. Марковић, Запис о политичким идејама др Људевита Мичатека, рад предат за други тематски зборник Српско-словачке везе, из историје, садашњости и будућности, Нови Сад 2014.

${ }_{18}$ Детаљније вид. и: Иштван Бибо, Беда малих источноевропских држава, Сремски Карловци 1996.

19 Детаљније вид. и: Зборник Присаједињење Војводине Краљевини Србији 1918, Нови Сад, 1993

${ }^{20}$ G. Gubobvá, Op. cit., 39.

21 Записник Словачке народне странке за Бачку и Срем, 10. новембар 1918. У Новом Саду, Збирка породице Мичатек, Ф-20, Историјски архив града Новог Сада (даље: ИАГНС), инв. бр. 442

22 Детаљније вид. и: С. Марковић, Политиканство или пролегомена..., 415-432.
} 
Владом Краљевине Србије. Друга група, знатно бројнија, била предвођена Радикалном странком и њиховим лидером Јашом Томићем, сматрала је да Банат, Бачка и Барања треба да се припоје Краљевини Србији из конкретних националних и политичких интереса. Словаци су услед формирања Републике Чехословачке били наклоњени републиканским идејама, ${ }^{23}$ односно у овом случају демократској струји, али су временом тесним војно-политичким повезивањем Краљевине Срба, Хрвата и Словенаца са Републиком Словачком у савез Мала антанта показали лојаност парламентарној монархији династије Карађорђевић.

Упркос оштрим полемикама које су јој претходиле, ${ }^{24}$ на Великој скупштина Срба, Буњеваца и осталих Словена, а која је одржана 25. новембра 1918. године у Новом Саду, донета је одлука о присаједињењу Краљевини Србији. У раду скупштине учествала су и 62 представника словачке националности. Лидер Словачке народне странке Људевит Мичатек ${ }^{25}$ је поздравио ову одлуку. „Na základe prirodzeného práva samourčovania národov žiadame si, aby sme boli pričlenení ku države Srbov, Horvatov a Slovincov v tom istom presvedčení, že v bratskej države rovnoprávnost' a rovnocennost’ národov uznaná, šetrená a zachovaná bude.“26

Одлукама скупштине ${ }^{27}$ Војводина је присаједињена Краљевини Србији и формирани су нови органи управе - Велики народни савет и Народна управа. Састав ових органа управе, у политичком смислу, био је показатељ постигнутог страначког компромиса. Упркос врло одговорном приступу у раду, без државног апарата, Народна управа морала је да тражи сигурност свог рада кроз подршку Краљевине Србије. Уједно то је био и начин да се донете одлуке на Великој народној скупштини реализују. „Народна управа чијој су бризи поверени јавни послови у оном прелазном стању састављена из најразнороднијих елемената, а на основи партијске слоге, лута без правца у хаосу нових проблема. Сама изгледа једва чека, да пребаци свој терет на вичнија и јача плећа. ${ }^{28}$ Неостварени демократски концепт, ${ }^{29}$ делом разумљив услед неубичајених прилика ратног примирја, Велика народна скупштина покушала је да надомести одређеним одлукама које су уважавала права свих националних заједница на њеној територији. ${ }^{30}$ Велики народни савет бројао је

\footnotetext{
${ }^{23}$ Детаљније вид. и: G. Gubobvá, Op. cit., 39.

24, „Пвв реч је добио Петар Коњовић као изасланик из Загреба. Он је према директиви, а на основу изјаве Момчила Нинчића, министра иностраних послова предложио да се Војводина прикључи Загребу, односно Хрватској а не Београду односно Краљевини Србији. Овај предлог је пропраћен бурним негодовањем. Настаје жучна дебата у којој су најактивнији били Јаша Томић, који је тврдио, да му је Нинчић рекао да се Војводина прикључи Србији... Настаје жучна дебата...“ Припреме за Велику народну скупштину 25. новембра 1918, Историјски архив, Сомбор, Ф-56, инв. бр. 577.

${ }^{25}$ Детаљније вид. кратке биографије у рукопису прихваћене за објављивање у Српском биографском речнику: С. Марковић, Мичатек, Људевит и Мичатек, Владимир.

${ }^{26}$ Andrej Labath, Naša politika od prevratu do dnes, Bački Petrovac 1932, 23-24.

27 Одлуке Велике народне скупштине и допунске одлуке, детаљније вид.: Споменица ослобођењь Војводине 1918, РОМС, М 7417.

28 Душан Поповић, војводина после уједињења, РОМС, М 7528.

29 Детаљније вид. и: З. Јањетовић, Деца ияарева, пасторчад краљева, Београд 2005.

${ }^{30}$ Допунске Одлуке:

„Несрпским и несловенским народима, који остају у нашим границама обезбеђује се свако право, којим желе да као мањина очувају и развијаују своје биће. А исто тако, захтева скупштина ова, да се оним Србима, Буњевцима и Шокцима, који и даље остају изван наших граница у другим државама, обезбеди
} 
педесет чланова, а међу њима је било и пет Словака: др Мичатек, Зденко Крно, ${ }^{31}$ Јанко Буљик, Јан Груњик и Само Штраке. ${ }^{32}$ Уважавајући чињеницу да је просветна политика била патосни елемент националне политике, Словаци су, попут Срба, ${ }^{33}$ од самог стварања нове државе, а имајући екстремно репресивна искуства током живота у Аустроугарској монархији, као уосталом и сви народи који нису припадали владајућем, инсистирали на очувању својих образовних институција. „Školstvo národne, aby sa každy národ dl'a svojho národneho razu mohol vzdelavat' a vyviňovat' a tak dl'a svojich syl prispiet' ku všeobecnemu vzdelávaniu a dobru. Čisto l'udove a národne školstvo, bez rečoveho utisku, nižšie i stredne a odborne školstvo (hospodárske, priemyselne atd'.) v ramcoch všeobecných slobodne ustálenie učebneho plánu, pomerne napomahanie so strany štátu, na strednych i vysokych školách povinne vyučovanie rečiam a literaturi krajinu obyvajúcich národov, ako i katedru reči a literatury na univerzitach. Učitel'ske prípravovne a semeništia kňažske maju byt' s naukosdelnou rečou patričnych veriacich založene a upravene. ${ }^{\text {(334 }}$

\section{Потрага за политичким изразом идентитета у југословенској држави}

Након демисије Народне управе, ${ }^{35}$ Словаци учествују и у избору представника за Привремено народно представништво Краљевства Срба, Хрвата и Словенаца, а чија је улога била да припреми изборе за Уставотворну скупштину. Несугласице које су пратиле и ове изборе за 24 представника колико их је било предвиђено, из Војводине нису мимоишле ни словачки политички корпус. До раскола је дошло на седници Великог народног савета 26. фебруара 1919. године. На том састанку, брзоплето организованом и једном већ прекинутом, сукобиле су се две концепције. Радикали су се залагали за сазивање народне скупштине као тела које једино може да изабере представнике, док су демократе сматрале да је национална егзалтираност ишла наруку њиховим опонентима и желели су да представнике бира

\footnotetext{
право заштите мањина, њихов народни опстанак и развитак на начелу реципроцитетеа.“; Споменица ослобођења Војводине 1918, РОМС, М 7417.

31 Зденко Крно је био и командир страже на Петроварадинској капији на којој је 9. новембра 1918. са радошћу и поверењем дочекана српска војска. Детаљније вид. и Ј. Сирацки, Велика Народна скупштина и Војвођански Словаии, Зборник „Присаједињење Војводине Краљевини Србији 1918“, Нови Сад 1993.

32 „Приступа се избору Народне Управе за Банат, Бачку и Барању према одлуци Народне скупштине. Једногласно се бирају ови народни повереници и заменици за одсеке: Председништво и политички послови - Народни повереник: др Јован Лалошевић, заменик: Петар Коњовић...“; Записник седнице Великог народног савета од 14. новембра 1918; Архив Војводине (даље: АВ), Ф. 76 Народна управа за Банат, Бачку и Барању, Нови Сад (1918-1919), 3 - Велики народни савет - записници.

${ }_{33}$ Детаљније вид.: Саша Марковић, Просветне политике у Војводини у време присаједињења Краљевини Србији, Зборник радова, Јагодина 2011.

${ }^{34}$ Shromaždenie Narodnej strany z Bačky a Sriemu. In Dolnozemsky Slovak r. 13, č. 1-2, 1. dec. 1918, s. 6-8; цитирано према G. Gubobvá, Op. cit., 41.

35 „Г. министар председник Протић је на наше питање децидирано одговорио да и ове покрајине дакле и Банат и Бачка и Барања чине саставни део јединствене државе Срба, Х.С. те да се власт централне владе простире и на ове територије. Према томе дакле сасвим је природно да двема владама на једном територију нема места, те да ова Народна управа треба да демисионира, што смо и закључили да учинимо.“; Записник вођен на седници Народне Управе у Новом Саду, 14. децембра 1918; АВ, Ф.7 6, 4, бр. 12.
} 
Велики народни савет. ${ }^{36}$ Победом концепта Радикалне странке већ сутрадан је одржана Скупштина која је изабрала представнике за Привремено народно представништво. ${ }^{37}$ Очекивано, представници Радикалне странке су доминирали. Неусаглашеност није мимоишла нити политичке представнике Словака. Лидерска концепт вођства Словачке народне странке утицао је и на полемике које су се у јавности рефлектовале као сукоб снажних појединаца. Председник странке др Људевит Мичатек био је близак демократским круговима и давао је подршку њиховим гледиштима у овом периоду. Његов опонент био је Игор Штефаник који је почетком 1919. постао члан Радикалне странке и њен кандитат за Привремено народно представништво. Своју политичку позицију је и Штефаник манифестовао приврженошћу југословенској држави. „Horvati i Slovenci, vojvodianski Bunevci, Šokci i Srbi a s nimi spolu i my Slovaci nadšeno a oduševnene pridrúžili sme sa tejto našej novej vel'kej slávnej države s tym ciel'om, aby v nej fakticky zjednotení boli všetci Slovania, ktorý na jej zemiach prebývame... My vojvodinský a sriemski Slováci s telom, dušou pridružujeme sa Král'ovstvu SHS, ktorému budeme verní synovia....“38

Словачка народна странка се није слагала да један од двојице припадајућих представника Словака за привремено представнштво буде Игор Штефаник уз подршку Радикалне странке а у име Словака. Странка је сматрала да је то било противно интересима словачке заједнице. „На радикално-социјалистичкој скупштини 27. фебруара биран је био, као представник Словака г. Игор Штефаник усупрот нашем протесту и он против изричне забране наше Народне Словачке странке примио је тај мандат. 28. августа 1919. Била је велика конференција наше странке у Петровцу са великим бројем делегата из свију крајева, где је г. Штефаник видећи да његов поступак огромном већином није одобрен, изјавио да иступа из Словачке Народне странке.“39 Штефаник није прихватао овакве класификације и сматрао је да је странку узурпирао др Људевит Мичатек за промоцију властитих идеја и интереса своје породице. „Pán dr. Mičatek započína si podl’a vyšneho nápisu. Pomocou svojho familiárneho žurnála, Dolnozemského Slováka, napáda, upodozrieva píše hrozí sa po národnych l’udoch ktori pracujú na statočnom národnom diele.“40 Штефаников говор у Привременом народном представништву био је идентичан наратив већ изречених идеја о одобравању новоформиране државе и представници су га јасно одобрили. „Ми Словаци, већ подвапут искрено смо изјавили, да се ми одушевљено придружујемо и прикључујемо овој нашој држави - Краљевини Срба, Хрвата и Словенаца (бурно пљескање и одобравање). Нама Словацима особито је досадио аустро-угарски јарам, који смо носили на нашим леђима по сто и сто лета. Немамо ми никакве воље да тај аустро-угарски јарам заменимо сада је ли са талијанским, је ли са румуњским. (Живио одобравање и гласови : ’Тако је'). Ми то

\footnotetext{
36 Записник седнице Великог Народног Савета у Новом Саду 26. фебруара 1919; АВ, Ф. 76, Народна управа за Банат, Бачку и Барању, Нови Сад (1918-1919), 3 - Велики народни савет - записници.

37 Детаљније вид.: Саша Марковић, Политичка биографија Јована Јоце Лалошевића, Сомбор 2011.

${ }_{38}^{38}$ Priveta Igora Štefanika, 23. март 1919, Збирка породице Мичатек, Ф-20, ИАГНС, инв. бр. 461.

39 Писмо Председништва Словачке народне странке Верификаиионом одбору Привременог народног представништва од 20. октобра 1919; Збирка породице Мичатек, Ф-20, ИАГНС, инв. бр. 458.

${ }^{40}$ Igor Štefanik, Bôh na nebi a dr. Mičátek v Juhoslávií, Збирка породице Мичатек, Ф-20, ИАГНС, инв. бр. 467.
} 
тражимо, да овде на овоме југословенском земљишту сви који смо Славјани будемо уједињени. Ево, драга моја браћо, неколико десетина хиљада словачких јунака, који су на вашој страни!“‘41

Растрзани између политичких опција Словаци су демонстрирали и амбивалентан карактер свог политичког деловања. Њихова наклоност била је предвиђена за оне моћније страначке групације које су умешније прихватале задовољења интереса Словака. Руководство странке је у намери да очува идентитет сународника преговарало са водећим странкама о евентуалној подршци. Ти преговори били су актуелни од избора до избора који опет нису мањкали у скромном парламанетарном искуству Краљевине Срба, Хрвата и Словенаца. Мотив разговора, услед темпираног предизборног периода, сводио се на изборну комбинаторику која je стратешка политичка опредељења сводила на политиканство ad hoc. На првим изборима за Уставотворну скупштину, Словачка народна странка била је део листе Демократске странке, да би на изборима од марта 1923. били на листи Стојана Протића. На изборима од 8. фебруара 1925. Словачка народна странка је била уз Радикалну странку као и на изборима $1927 .{ }^{42}$

Сачувани историјски извори указују на врло отворене разговоре са нескривеним намерама. „Господин Никола Пашић председник министарства, шеф радикалне странке у Београд. У име Словачке Народне Странке у Краљ. С.Х.С. част нам је молити порадити својим упливом, на томе, да би наша странка приликом предстојећих избора могла кооперирати са радикалном странком... Београд 1. јануар 1923. С поштовањем Др. Л. Мичатек, председник. Јан Булик тајник.“43 Радикали су били спремни да изађу у сусрет одређеним захтевима и последица тога било је коалиционо савезништво. Ипак, оно није било дуготрајно а, између осталог, условљавала га је и амбиција Радикалне странке да инкорпорира политичку представничку организацију Словака у своју страначку структуру локалног карактера. „Да се Словаци уписују у Народну Радикалну Странку као Секција Словачка, али да имају за сваку област свој Управни Одбор, који држи везе преко Акционог одбора у Војводини са Главним Одбором у Београду““44

Када се у компромисима науштрб програма ишло превише далеко, долазило је до осипања дела руководства које није сматрало да је то било неопходно. Тако је др Мичатек поднео оставку на место председника странке, али је и даље учествовао у изборним активностима као члан Демократске странке. Његов одлазак представљао је крупан догађај у политичкој историји војвођанских Словака. Разлог се крио у томе што је Мичатеков концепт, подупрт значајним образованим појединцима, био заснован на идеји културно-просветне консолидације Словака и страначког либерализма. Странка је временом постала прилепак моћнијих

${ }^{41}$ Говор Игора Штефаника на шестом редовном састанку Привременог народног представништва Краљевства Срба, Хрвата и Словенаца; Стенографске белешке Привременог народног представништва Краљевства Срба, Хрвата и Словенаца држан 23. марта 1919, стр. 72-73.

${ }_{42}^{4}$ Andrej Labath, Naša politika od prevratu do dnes, Bački Petrovac 1932, 99-101.

${ }^{43}$ Писмо Николи Пашићу, Збирка породице Мичатек, Ф-20, ИАГНС, инв. бр. 507.

44 Писмо Љубе Јовановића, председника Извриног одбора Народне Радикалне Странке у Београду Председништву Народне словачке странке од 11. децембра 1924; Збирка породице Мичатек, Ф-20, ИАГНС, инв. бр. 512. 
грађанских странака и онемогућила је јединствен политички иступ Словака јер су они који се нису слагали са понуђеним савезништвом поверавали самоиницијативно свој глас другим програмима.

Реакција на овакву ситуацију био је конгрес Словачке народне странке одржан у Петровцу 3. априла 1927. године. На овом конгресу није прихваћен Мичатеков концепт и делегирани чланови странке преиначили су назив странке у Словачка народна ратарска странка Краљевине Срба, Хрвата и Словенаца (Slovenská narodná rol'nícka strana v kral'. SHS) и донели нов програм. Већ је назив странке указао да је фокус на аграрним интересима, што је било разумљиво с обзиром на то да су социјалну структуру Словака у Југославији доминантно чинили земљорадници. Ова усредсређеност указала је и на постојеће незадовољство спроведеном аграрном реформом чији је редукциони социјални призвук не само успорио привредни развитак већ изазвао и нове проблеме са све бројнијом арграном сиротињом. ${ }^{45}$ „Agrarna refoma: Žiadame, aby sa agrárna reforma spravedlive prevadzala a pri tom, aby sabral zretel' aj na našu chudobu v tej istej miere, ako čo sa berie ohl'ad i na chudobne vrstvy národa srbsko-horvatsko-slovienského.“46 Чланови програма странке инсистирали су на: праву на образовање на народном језику, економији заснованој на развоју пољопривреде, јавним радовима, примереној администрацији, одговорној кадровској политици као и стратегији образовања, на којој се нарочито инсистирало и пре. ${ }^{47}$ Нови реорганизациони председник станке постао је Михал Ружек из Пивница. Неподношљивост национализама и одсуство спремности на договор условили су пораз парламентаризма у познатим догађајима у Народној скупштини јула 1928. године. Уследило је увођење диктатуре. Након тога и Словачка народна ратарска странка прекинула је са радом и више није обнављала своје активности све до распада земље 1941. У условима када је страначки рад био забрањен, Словаци, односно представници словачких културних и црквених установа, окупљени око тзв. Одбора који је предводио Јанко Буљик, обратили су се краљу Александру Карађорђевићу меморандумом који представља израз њихових виталних интереса. Инсистирали су на стварима које је и странка уврстила у свој програм а које су се односиле на право на школовање, веру, административне представнике и привредно деловање. „У нашим словачким општинама молим, да се постављају првенствено управни чиновници по реду и језику Словаци... У нашем настојању за националним опстанком сматрамо школу и просвету у опште као најважније и најјаче средство, стога молимо, да се нашим захтевима из овог оделења посвети највећа пажња... Да се словачким евангелицким црквеним општинама хонорира употреба њихових школсских зграда и земље у форми закупнине...“48 ${ }^{4}$ меморандуму је истакнуто

\footnotetext{
${ }^{45}$ Детаљније вид.: Никола Гаћеша, Аграрна реформа и колонизација у Бачкој 1918-1941, Нови Сад 1968.

${ }^{46}$ A. Labath, Op. cit., 65.

47 „Школа има у првом реду да васпитава за живот. За наш народ потребне су у првом реду добре пољопривредне и индустријске школе, али оне нека су онда узорне и добро снабдевене стручно васпитним снагама а не полуваспитним. Без стручне, напредне пољопривреде нећемо моћи напредовати, поготово кад смо агрикултурна држава."; Јан Чајак, Војвођани о Војводини, поводом десетогодишњице ослобођењ а и уједињена, 1928, 19.

${ }_{48}$ Меморандум представника словачких културних и ирквених установа од 21. новембра 1929.; Збирка породице Мичатек, Ф-20, ИАГНС, инв. бр. 529.
} 
нескривено задовољство што су у новој административној подели државе Словаци остали углавном на простору Дунавске бановине. „Представници словачких културних и црквених установа сакупили су се данас у Новоме Саду у циљу претресања словачких културних потреба те задовољни што је услед новога бановинског уређења свих 70.000 Словака у Краљевини Југославији припало у једну управну јединицу бановине Дунавске.“49 Неприкосновени лидер ове народне културне политике био је др Јанко Буљик, дугогодишњи сарадник др Људевита Мичатека. Након Мичатекове смрти ${ }^{50}$ др Буљик је својом упорношћу, а уважавајући политичку ситуацију након 6. јануара 1929. године, и у сарадњи са матичном државом која је имала изузетно добре односе са Краљевином Југославијом, ${ }^{51}$ радио на оснивању Матице словачке. Њен задатак је био да препозна и даље развија права Словака у Војводини уз ослонац на традиционалне вредности, фолклор и обичаје. Матица словачка била је основана маја 1832 . године. ${ }^{52}$

Иако странка није обновила рад, Јанко Буљик се није одрекао свог политичког ангажмана. Јединствена режимска странка, Југословенска радикалносељачка демократија, ${ }^{53}$ како је притисак државних власти попуштао, добијала је све гласније критике свог рада и утицала на јединствено опозиционо окупљање. Под утиском ставова о демократизацији друштва и о уставним реформама изнетим у тексту тзв. Загребачке пунктације, ${ }^{54}$ а иза којих је стајала Сељако-демократска коалиција, и у Војводини, најпре у Сомбору, донета је резолуција са ставовима који су се односили на потребу политичке препознатљивости Војводине. Тада се јављају и прве посвећеније расправе о уставном положају Војводине. Предводници ових полемика су били подједнако и чланови Народне радикалне и Самосталне демократске странке из Војводине. Њима се у вези са доношењем Новосадске резолуције уједињене грађанске опозиције придружио и др Буљик. Прва Новосадска конференција била је одржана 11. децембра 1932. године на иницијативу опозиционих радикала из Војводине, а формално је Конференцију сазвао првак самосталних демократа из Новог Сада Александар Моч. Састанку је присуствовало 37 заинтересованих учесника. ${ }^{55}$ Највећи број њих припадао је грађанским

\footnotetext{
${ }^{49}$ Исто.

${ }^{50}$ Некролог др Људевит Мичатек, Народ, орган војвођанске демократије, 15. јул 1928; I Chalupecký, Mičátek Ludovit Österreichisches Biographisches Lexikon und biographische Dokumentation http://www.biographien.ac.at/oebl/oebl_M/Micatek_Ludovit_1874_1926.xml / У овој аустријској биографији је грешком написано да је Људевит умро 1926. године.

${ }_{51}$ Deklarace o školských a kulturních stycích Československé republiky s Královstvim Jugoslavie - У Београду 13. Листопада 1929. у Прагу 23. Јануар 1930. Збирка породице Мичатек, Ф-20, ИАГНС, инв. бр. 531.

52 Детаљније вид. и: Matica slovenská v Juhoslaviji 1932-1941, Hlas L’udu, Báčsky Petrovec, 31. marec 1990.

53 Детаљније вид.: Саша Марковић, Интегрално југословенство у Војводини - одјек и страначко одређење; Зборник радова „The Shared History - Myths and stereotypes of the Nationalism and Communism in ex Yugoslavia“, Novi Sad 2008.

${ }_{54}$ Детаљније вид.: Љубо Бобан, Загребачке пунктације, Историја XX века, Зборник радова IV, Београд 1962.

55 О присутнима на састанку вид.: Историјски архив, Сомбор, Ф-57, инв. бр. 328, 329; Ранко Кончар, Новосадска резолуција из 1932. године, Зборник Матице српске за историју, бр. 8, Нови Сад 1973, 134 и Опозиционе партије и аутономија Војводине, Нови Сад 1995, 101; С. Марковић, Грађанске опозиционе странке у Војводини 1929-1941, Нови Сад 2006, 71.
} 
странкама, а међу присутнима био је и др Буљик. На овој конференцији демонстрирана је јединственост става у вези са сложеним и тешким политичким и привредним стањем у којем се нашла Војводина, с једне стране, али и различити погледи и мишљења о начину решавања постојећих проблема, с друге. Из дискусије је проистекао став о оснивању војвођанске странке али се др Јанко Буљик успротивио тој идеји. ${ }^{56}$ Извор нам сведочи о једној обазривој и одговорној дискусији вођеној с намером да се смири радикализација неспоразума који је у том тренутку већ био очевидан унутар грађанских странака и то на релацији централа у Београду и појединих њихових представништва и чланова из Војводине.

Зенит политичке активности око Новосадске резолуције био је прокламовање Војвођанског покрета у оквиру којег је учествовао и Јанко Буљик и њихове активности у вези са општинским изборима ${ }^{57}$ у Војводини 1936. године. ${ }^{58}$ По његовом мишљењу, које је прихваћено као платформа, ${ }^{59}$ ово је била јединствена прилика да се покаже у којој мери се политичари из Војводине, без обзира на националну припадност, руководе идејом да им је до ње стало али са намером да она својим развојем обогати привредни и демократски развој друштва. Била је то и понуђена могућност да се оповргну све сумње у сепаратизам и релаксира нарасли политички антагонизам и национална анимозност. Учешће Словака у политичком животу Краљевине Југославије 1929-1941. године постало је индивидуалан чин и слободан избор, али и нереалан занос поверења у могућности. Континуитет се налазио у антифашизму ${ }^{60}$ од којег су горњоземски Словаци међу првима страдали убрзо је та ситуација задесила и долноземске Словаке, односно Словаке у Краљевини Југославији. Корифеј њихов био је и остао Јанко Буљик, убијен у нацистичком логору 1942. године.

\footnotetext{
56 „Након дискусије Словака Ј. Буљика да је преурањено оснивање једне војвођанске странке и да је у овом тренутку боље да присталице појединих странака изнесу своја гледишта страначким руководствима, као и слагања са тим В. Прибићевића, Јакшић је повукао свој предлог, остављајући га за неко адекватније време.“; С. Марковић, Грађанске опозиционе странке у Војводини 1929-1941, 73.

57 „Војводина, истински права и потпуно сељачка Војводина! Стоји и чека, свесна да стоји пред одлучним моментом, јер је чекају општински избори 6-тог децембра ове године."; Војвођанин, 28. 11. 1936.

58 Детаљније вид.: С. Марковић - Д. Гавриловић, Војвођански покрет између јединствене политичке платформе и страначких интереса, Истраживања, бр. 24, Нови Сад 2013.

59 „Први пут од како постоји Војводина сада су се споразумели Срби, Немци, Словаци и Мађари да треба водити политику од које ће имати корист Војводина."; Дан, 23. и 27. јула 1935.

60 „Нема већег понижења за човечанство него питање, дали ауторитативни режими имају предност над демократским."; Војвођанин, 18. 4. 1937.
} 


\section{Извори и литература:}

Извори:

Рукописно одељење Матице српске (РОМС)

Историјски архив Сомбора

Историјски архив града Новог Сада

Архив Војводине (АВ)

Стенографске белешке Привременог народног представништва Краљевства Срба, Хрвата и Словенаца

\section{Литература:}

Babiak, Jan - Surovy, Rastislav, Atlas l'udovej kultúry Slovákov v Juhoslávii, Báčsky Petrovec 2002. Бибо, Иштван, Беда малих источноевропских држава, Сремски Карловци 1996.

Бјелица, Слободан, Радикали у Војводини 1919-1929, Београд 2005.

Бјелица, Слободан, Трансформаиије идеје о аутономији Војводине, Зборник Матице српске за друштвене науке, бр. 137, Нови Сад 2011, 509-520.

Бјелица, Слободан, Војвођански радикали и Словаии, Зборник радова „Српско-словачке везе“, Трнава 2013, 90-97.

Војвођани о Војводини, поводом десетогодишњиие ослобођења и уједињења, 1928,

Boldocký, Samuel, Ján Bulik (1932-1935), 80 rokov Matice slovenskej v Juhoslávii/Srbsku, Zbornik prác. Gl. ur. Samuel Boldocký, Báčsky Petrovec 2012.

Gubobvá, Gabriela, Slovenská mensina v kontexte poltických udalostí v Královstve SCHS 1918 1929, докторска дисертација, Братислава 2009.

Гаћеша, Никола, Аграрна реформа и колонизација у Бачкој 1918-1941, Нови Сад 1968.

Глигоријевић, Бранислав, Политичка иступаға и организација Словака и Чеха у Краљевини СХС, Зборник Матице српске за историју, бр. 24, Нови Сад 1981, 137-155.

Димић, Љубодраг, Историја српске државности, Србија у Југославији, Нови Сад 2001.

Dr. Janko Bulik, vlastenec, demokrat a martýr, Matica slovenská, 2007.

Дугачки, Влатка, „Мањинска посла“ - политичко организирање чешке и словачке мағине на изборима за Уставотворну скупштину, Загреб 2012, 389-413; file://C:/Users/sasa/Downloads/7_Dugacki_CSP_2012_2.pdf

Зборник Присаједињење Војводине Краљевини Срббији 1918, Нови Сад 1993.

Labath, Andrej, Naša politika od prevradu dodnes, Bački Petrovac 1932.

Лебл, Арпад, Грађанске партије у Војводини 1887-1918, Нови Сад 1979.

Љубо, Бобан, Загребачке пунктаиије, Историја XX века, Зборник радова IV, Београд 1962.

Јаси, Оскар, Будућност Монархије: пропаст Двојне монархије и сједињене подунавске земье, Сремски Карловци 1996.

Kmeć, Jan, Slovačko-srpska saradnja u matičnom duhu krajem prošlog i početkom ovog veka, Novi Sad 1992.

Kmeć, Jan, Vlastita logika slobode slovačke nacionalne manjine u Vojvodini. Politički položaj manjina u Saveznoj republici Jugoslaviji, Beograd 1996.

Kovačica pamatá: zbornik z vedeckeho sympozia Kovačica pamat, Matica Slovenská, Slovakia, 2007. 
Кончар, Ранко, Новосадска резолуција из 1932. године, Зборник Матице српске за историју, бр. 8, Нови Сад 1973.

Кончар, Ранко, Опозиционе партије и аутономија Војводине, Нови Сад 1995.

Кончар, Ранко - Марковић, Саша, Vojvodina beetwen Serbian and Yugoslav option during the establishment of the Kingdom SCS, тематски зборник радова са међународног скупа „Yugoslavia through Time. Ninety Years since the Formation of the First State of Yugoslavia“, Ljubljana 2009, 93-105.

Марко, Јан, Kovačičania Vysokoškolaci, Kovačica, 1992.

Марковић, Саша, Грађанске опозиционе странке у Војводини 1929-1941, Нови Сад 2006.

Марковић, Саша, Национално и уставно питање у делатности странака у Војводини 19291941, докторска дисертација, Нови Сад 2008.

Марковић, Саша, Интегрално југословенство у Војводини - одјек и страначко одређење, Зборник радова „The Shared History - Myths and stereotypes of the Nationalism and Communism in ex Yugoslavia“, Novi Sad 2008.

Марковић, Саша, Политичка биографија Јована Јоче Лалочевића, Сомбор 2011.

Марковић, Саша, Просветне политике у Војводини у време присаједиъења Краљевини Србији 1918, Зборник Радова, Педагошки факултет, Јагодина 2011.

Марковић, Саша, Политиканство или пролегомена Демократске странке код војвођанских Срба Аустроугарске монархије, Истраживања, бр. 23, Нови Сад 2012.

Марковић, Саша, У потрази за политичким идејама Јанка Буљика, Зборник радова „Српскословачке везе“, Трнава 2013, 98-116.

Марковић, Саша - Гавриловић, Дарко, Војвођански покрет између јединствене политичке платформе и страначких интереса, Истраживања, бр. 24, Нови Сад 2013.

Марковић, Саша - Гавриловић, Дарко, Војвођански покрет између јединствене политичке платформе и страначких интереса, Истраживања, бр. 24, Нови Сад 2013.

Matica slovenská v Juhoslaviji 1932-1941, Hlas Ludu, Báčsky Petrovec, 31. marec 1990.

Народы Габсбурсгской монархии в 1914-1920 г2.: от начиональных движений к созданию национальных государств, выпуск 6, том 1, Москва 2012

Петрановић, Бранко, Историја Југославије 1918-1978, Београд 1981.

Петрановић, Бранко - Зечевић, Момчило, Историја Југославије 1918-1988, Збирка докумената, Београд 1988.

Петрановић, Бранко - Зечевић Момчило, Југословенски федерализам, Идеје и стварност, тематска збирка докумената, Београд 1987.

Поповић, Душан, Банат, Бачка и Барања, Нови Сад 1935.

Штампа:

Војвођанин, Дан, Народ, Народна једнота. 


\title{
POLITICAL CHALLANGES OF SLOVAKS IN VOJVODINA CONCERNING THEIR IDENTITY 1919-1941
}

\begin{abstract}
Summary
In the period from 1918 to 1941 political actions of Slovaks in Vojvodina, i.e. within the Kingdom of Yugoslavia, were at first filled with hope. Slovaks welcomed the idea of a south-Slavic state and even participated in their creation through their political representatives. Their most prominent representatives, such as Ljudevit Mičatek, Vladimir Mičatek, Janko Buljik, Igor Štefanik, were all Yugoslav patriots, but also their national community's patriots. Cultural and economical needs had crucial influence on the concept of Slovak political programme. Their party was the Slovak National Party, which was renamed to Slovak National Farmers' Party in 1927. Cooperation of this party with the leading citizens' parties was directed by the ambition to optimally fulfil the interests of Slovak community. There were also personal animosities present among the leading Slovak representatives, which consequently influenced the political articulation. After the introduction of the Dictatorship in 1929 the activity of Slovak party ceased and was never renewed. In 1932 Slovaks formed the Slovakian Matica (Matica slovačka), whose president became Doctor Janko Buljik. Already at the end of the same year, he became politically active in relation to the signing of the Resolution of Novi Sad. His motives for this engagement were not a result of his supporting the separatism of the state, but the economical progress not only of Vojvodina but the entire country as well. Behind this patriotism of Slovaks in Vojvodina (the so called Lowland Slovaks), there were exceptional state relations between the Republic of Slovakia and the Kingdom of Yugoslavia in the time before the Second World War.
\end{abstract}

Keywords: Slovaks, politics, party, idea, identity. 